\title{
DAPK1 Gene
}

National Cancer Institute

\section{Source}

National Cancer Institute. DAPK1 Gene. NCI Thesaurus. Code C60652.

This gene is involved in pro-apoptotic regulation. 